\title{
Influence of Storage of Wet Arabica Parchment Prior to Wet Hulling on Moulds Development, Ochratoxin A Contamination, and Cup Quality of Mandheling Coffee
}

\author{
Pengaruh Penyimpanan Biji Kopi Arabika Mandheling Bercangkang Sebelum \\ Pengupasan Basah, terhadap Perkembangan Jamur, Kontaminasi Ochratoxin A, \\ dan Mutu Seduhan
}

Cahya Ismayadi ${ }^{1)}$, Budi Sumartono ${ }^{1)}$, Anthony Marsh²) and Renata Clarke ${ }^{3)}$

\begin{abstract}
Summary
Mandheling coffee has been a well known specialty coffees for decades and the demand for this coffee is currently increasing. This coffee is characterised by low acidity, heavy-complex body, spicy-little earthy and fruity flavor. Mandheling coffee is produced by smallholder farmers in the highland surrounding Lake TobaNorth Sumatra in an unique way i.e. following de-pulping and 1-2 days sundrying, wet parchment is stored for varying periods up to a few weeks, the parchments are then de-hulled when still wet (40-45\% moisture content) then the beans sundried. The handling procedure presumably contributes to the unique cup character of Mandheling coffee. On the other hand the storage of wet pachments may cause mould growth and mycotoxin contamination. This trial was designed to study the influence of storage of wet parchments prior to wet hulling on mould development, OTA contamination and cup Mandheling characteristic of the coffee product. The normal wet process, drying of parchment thoroughly to $12 \%$ moisture content was used as the control. Parchment coffees (6 lots) used for this trial were drawn from farmers and collectors in the region. The wet parchments (41.74-53.96\% moisture content) were stored for 1 (D1), 7 (D7) and 14 (D14) days in PE sacks in a warehouse in the region. During the storage period, when there was visible mould growth, the parchments were spread on a plastic sheet inside the warehouse, as per common practice to suppress the mould growth. Following storage, the wet parchment was de-hulled and then sun-dried to a moisture content of $12 \%(\mathrm{MC} 12 \%)$ or dried to a moisture content of $17 \%$, and held in storage for 3 weeks prior to final drying to $12 \% \mathrm{mc}$. The 'normal wet process' i.e. fresh-non stored parchments dried thoroughly to $12 \%$, were used as the control. Parameters measured were visual evaluation, mould infestation, $\mathrm{a}_{\mathrm{w}}$, moisture content (MC) on the stored parchment; while for dried beans mould infestation, OTA content and the Mandheling cup character evaluation
\end{abstract}

1) Researcher and Technician (Peneliti dan Teknisi); Pusat Penelitian Kopi dan Kakao Indonesia, J1. P.B. Sudirman 90, Jember 68118 , Indonesia.

2) 12 Hight Street, Highfields, 4352, Queenland, Australia.

3) FAO UN, Vialle delle Terme Caracalla, 00100 Rome, Italy. 
(done by 4 panelists who were familiar to the coffee) were determined. Some mould species grew during the storage course, with black Aspergillus was the dominant species found in the beans, while A. ochraceus an OTA producer, was found in some samples with low infection rate $(0-15.3 \%)$. Spreading of coffee inside the warehouse during the day could suppress moulds growth. OTA was found in only 5 samples out of 42 samples with range of $0.17-2.24 \mathrm{ppb}$, very less than European Union limit. There was no clear trend of storage period on the mould infection rates, OTA content, and the Mandheling cup characters. The high variability of the outcome was likely due to the inhomogenity of parchments used for this trial. The best Mandheling was found in the sample of D1MC12\%-coffee source of lot 1 .

Key words: Mandheling coffee, storage, wet parchment, mould, ochratoxin A.

\section{Ringkasan}

Kopi Mandheling merupakan salah satu kopi spesialti yang terkenal sejak beberapa dekade sebelumnya dan permintaannya terus meningkat. Kopi tersebut mempunyai karakter seduhan yang unik yaitu low acidity, heavy-complex body, spicy-little earthy dan fruity flavour. Kopi tersebut diproduksi oleh petani kecil di dataran tinggi sekitar Danau Toba Sumatera Utara. Cara produksi khas, yaitu setelah pengupasan kulit buah dan penjemuran 1-2 hari, kopi bercangkang basah disimpan selama beberapa waktu sampai beberapa minggu, kemudian kopi bercangkang dikupas ketika masih basah (kadar air 40-45\%) diikuti dengan penjemuran cepat 3-4 hari. Praktek tersebut diduga mempengaruhi karakter seduhan kopi Mandheling. Di samping itu, penyimpanan kopi basah berpeluang menimbulkan serangan jamur dan kontaminasi mikotoksin. Penelitian ini mengkaji pengaruh penyimpanan biji bercangkang basah terhadap pertumbuhan jamur, kadar OTA dan karakter produk kopi Mandheling. Sebagai kontrol digunakan proses penjemuran kopi bercangkang tanpa disimpan sampai dicapai kadar air 12\%. Penelitian menggunakan enam lot kopi bercangkang basah dari petani dan pedagang pengumpul di lokasi produksi. Kopi bercangkang basah (kadar air 41,74-53,96\%), disimpan selama 1 (D1), 7 (D7) dan 14 (D14) hari dalam karung plastik di dalam gudang di daerah produksi. Kondisi biji selama penyimpanan diamati, apabila secara visual terjadi pertumbuhan jamur, biji dihamparkan dalam gudang guna menekan pertumbuhan jamur sebagaimana lazimnya. Setelah disimpan, biji bercangkang dikupas dan dijemur tipis sampai dicapai kadar air 12\% (MC12\%) atau sampai $17 \%$ (MC17\%) kemudian disimpan tiga minggu dilanjutkan penjemuran sampai 12\%. Proses pengolahan basah, yaitu biji bercangkang segar tanpa disimpan langsung dijemur sampai kadar airnya 12\%, digunakan sebagai kontrol. Parameter yang diukur meliputi pengamatan visual biji, $a_{w}$, kadar air, tingkat serangan jamur terhadap biji bercangkang yang disimpan, dan pada biji hasil pengeringan meliputi tingkat serangan jamur, kadar OTA, dan karakter seduhan Mandheling (dinilai oleh empat panelis yang berpengalaman pada kopi tersebut). Hasilnya menunjukkan bahwa beberapa spesies jamur tumbuh selama penyimpanan kopi bercangkang, dengan Aspergillus hitam ditemukan paling dominan, sementara 


\begin{abstract}
A. ochraceus (spesies penghasil OTA) ditemukan pada beberapa contoh dengan tingkat serangan ringan (0-15,3\%). Penghamparan kopi di dalam gudang pada siang hari dapat menekan pertumbuhan jamur. OTA hanya ditemukan pada lima contoh dari 42 contoh dengan kadar 0,17-2,24 ppb, jauh di bawah ambang Uni Eropa. Tidak terdapat hubungan yang jelas antara lama penyimpanan terhadap pola kontaminasi OTA, tingkat serangan jamur dan pembentukan karakter seduhan Mandheling. Hal tersebut diduga karena tingginya keragaman bahan kopi yang digunakan pada percobaan ini. Karakter seduhan Mandheling terbaik terdapat pada contoh hasil perlakukan D1-MC12\% asal kopi 1.
\end{abstract}

\section{INTRODUCTION}

Mandheling Coffee is one of the well known Indonesian specialty coffees produced in the area surrounding Lake Toba-North Sumatra. The coffee is exported through Blawan port since the early $20^{\text {th }}$ century together with Gayo Coffee which is produced on Gayo mountain in Aceh. Currently, the total production of Mandheling and Gayo coffees are more than 30,000 tonnes per year, accounting for over half of the total national production of Arabicas, with a value of more than US\$ 75 million per year. The coffee has premium price of about 1-2 US\$/ $\mathrm{kg}$, a significant value due to the unique cup characteristics and limited production. Both coffees are produced by small farmers with an average acreage of about 1-2 ha per farm. The coffee is mainly marketed in the USA and Japan. In last decades, the production has increased due to the high demand and price. New plantations in some districts in the high-land areas are currently expanding.

The Mandheling cup character has been described as having low acidity, heavy-complex body, spicy-little earthy and fruity flavor. Those characteristics are exist in a good Mandheling coffee, however some varia- tions might also be present in some of the product. The variations are likely hardly accepted by buyers, especially if there are taints. Traders who are specialised in this specialty coffee note that there is a growing variability in the quality of the Mandheling coffee that they buy. Unreliable quality could eventually undermine the market for this coffee and compromise the livelihoods of the small farmers that depend on this trade.

Several factors may contribute to the development of the "Mandheling flavour": among these, variety, agro-climatic conditions, farm management practices as well as processing and handling practices all along the market chain. The coffee is primarily produced in an unique way by small-scale farming system. Farmers harvest the fully ripe cherries, then de-pulp them by using a wooden hand-pulper on the same day of harvest or by the day after. After overnight fermentation, the parchment is washed manually, and then sun-dried for periods ranging from half of a day or up to two days. The wet (partly dried) parchments are then sold to local traders, usually at a local market which is open weekly. Small traders then sell the coffee to larger traders who have hulling machines and drying facillities. Here 
the wet parchment is de-hulled using a Engelberg type huller that is modified to use with wet parchment. The output beans, which are whitish in colour, are then sundried directly on a patio or on PE-plastic sheet for 3-5 days to achieve a moisture content of $14-17 \%$. After being cleaned by aspiration, the coffee is sold to exporters in Medan. At the exporter level, the coffee is re-dried (sun-dried) to $13 \%$ of moisture, cleaned, size graded, and hand sorted to remove defects. Variations to this general process occur: storage or of wet parchments ( $340 \%$ of moisture content) and storage of wet beans are quite common at farmer or trader levels. Trader store wet parchments inside their warehouse in woven PE sacks, and to suppress mould growth sometimes the parchment is spread on plastic sheets. At high moisture contents, coffee is subject to mould growth and quality deterioration. If conditions are suitable for the growth of toxigenic moulds, contamination with mycotoxins, such as ochratoxin-A, could result.

The presence of ochratoxin A (OTA) in coffee has become an issue and concern of the coffee industry (Romani et al., 2000). OTA is produced by some species of $A s$ pergillus and Penicillium such as $A$. ochraceus, $A$. carbonarius, $A$. niger (only few strains), and $P$. verrucosum (Frisvad \& Thrane, 1996; Ono et al., 1995).

European Union has put a limit on coffee products $(5 \mathrm{ppb}$ for roast and ground coffee and $10 \mathrm{ppb}$ for instant coffee) that came into effect at the beginning of 2005 . The importance of OTA prevention, by the application of good hygiene practices at all stages of production, has been emphasised. In case of Mandheling coffee, where the production and local trading is very vulnerable for mould growth due to the long handling of coffee in wet condition, the risk of OTA contamination in the coffee needs to be investigated.

In order to fulfill food safety requirements and meet commercial requirements, it is important that factors contributing to the Mandheling character be elucidated. Once the factors are understood, one can manipulate the production system to consistently achieve the desired cup characteristics, and to avoid food safety hazards. So far, there has been no investigation of the factors that influence the development of the Mandheling character. This trial was therefore designed to investigate the influence of selected processing and handling variables on the quality of Mandheling coffee. The conditions used were according to common practices in the coffee chain. The trial investigated the impact of the storage time of wet parchment (2, 7 and 14 days) on cap quality, mould and OTA contamination as compared with a control that was subjected to a 'standard' wet process. The trials also looked at the impact of incomplete drying of the green bean to $17 \%$ mc followed by storage for 3 weeks prior to drying to the recommended level of $12 \% \mathrm{mc}$.

\section{MATERIALS AND METHODS}

In order to represent the actual practice, this trial was set using 6 lots of wet parchments drawn from groups of farmers and local traders at different locations in 
the region (about $600 \mathrm{~kg}$ each). About 60 $\mathrm{kg}$ of parchments were taken from each lot and dried directly under sun on PE-sheets (as the control-normal wet process). The remainings were stored for 1 day (D1), 7 days (D7) and 14 days (D14). During the storage, lots of parchment was monitored everyday, when moulds visually appeared to grow the parchment was spread over on plastic sheets inside the warehouse to suppress the mould growth. Following each storage periods, the coffee was de-hulled by using a modified Engelberg hulling machine that designed for wet parchments. Parchments that have moisture higher than $45 \%$ were partially sun-dried to get moisture of $40-45 \%$, the suitable condition for wet hulling process by using the machine. Output beans (whitish in colour) were sundried on PE sheet (one layer thickness) to get moisture content of about 17\% (M2) and $12 \%$ (M1) respectively (took about 3 to 5 days). For lots of final drying of $17 \%$ moisture content were stored for 3 weeks then followed by re-drying to get moisture $12 \%$. All trial units (42 units in total consisted of 6 lots of controls and 36 lots of 6 coffee sources $x 3$ storage periods x 2 final moisture content drying, respectively) were stored in woven PE sacks until analyzed.

Parameters analyzed were visual appearence of stored parchments, $\mathrm{a}_{\mathrm{w}}$ of parchments (using Novasina ms1-aw, Pfäffikon, Switzerland), moisture content of parchments and green beans (based on the prosedure of ISO 6673), mould infestation in the beans (by direct plating of 98 beans on DG-18 medium, Samson et al., 1996).

OTA content in the beans was analyzed by using immuno-affinity clean-up and
HPLC procedure of Pittet et al. (1996) with slightly modifications. Extraction was using 3\% $\mathrm{NaHCO}_{3}-$ Metanol (50:50) (Nakajima et al.,1997) and purified on OchraTest $^{\mathrm{TM}}$ (Vicam, Palo Alto). HPLC system used was Shimadzu 10ADVP with conditions:

- Mobile phase: $50 \%$ acetonitrile-50\% 4 $\mathrm{mM}$ sodium acetate/acetic acid (19:1) with flow rate $1 \mathrm{ml} / \mathrm{min}$.

- Column: Shimpack CLC ODS, $5 \mathrm{~mm}$, $250 \mathrm{~mm} \times 4.6 \mathrm{~mm}$ i.d. equipped with pre-column: Shimpack G, $5 \mathrm{~mm}, 10 \mathrm{~mm}$ x $4.0 \mathrm{~mm}$ i.d.

- Injection volume : $20 \mathrm{ml}$.

- Detector : Fluorescence, Excitation: 330 $\mathrm{nm}$, Emission: $470 \mathrm{~nm}$.

- Detection limit of the procedure was $0.3 \mathrm{ppb}$.

Cup-taste evaluation was involving 4 international cuppers who are familiar with Mandheling characters. It consisted of:

- Mandheling character ratings: scored 10 (best) to 1 (worst) against their experience to Mandheling character low acid, heavy and complex bodied, spicy-little earthy-fruity flavour.

- Verbal comments: when appropriate cuppers provided their comments to each coffee tested, including defect off-flavours or taints.

\section{RESULTS AND DISCUSSION}

Coffee materials used for this trials were derived from local traders and group of farmers at central of coffee area in form of fresh parchments. Parchments received from local traders were collected from sur- 
Table 1. Origin, moisture content, and $\mathrm{a}_{\mathrm{w}}$ of parchment coffee used in the trial

Tabel 1. Asal kopi, kadar air dan $a_{w}$ dari kopi bercangkang yang digunakan pada penelitian

\begin{tabular}{|c|c|c|c|}
\hline$\overline{\text { Lot }}$ & Origin (Asal) & $\begin{array}{c}\text { Moisture content, \% } \\
\text { Kadar air, \% }\end{array}$ & $\mathrm{a}_{\mathrm{w}}$ \\
\hline I & Parik Sabungan, Sub-district Siborong-borong, District North Tapanuli & 42.21 & 0.921 \\
\hline II & Sipintu-pintu, Sub-district Siborong-borong, District North Tapanuli & 45.55 & 0.927 \\
\hline III & Silando/Sianjur, Sub-district Siborong-borong, District North Tapanuli & 41.74 & 0.929 \\
\hline IV & Tangga Batu, Sub-district Balige, District Toba Samosir & 44.58 & 0.926 \\
\hline $\mathrm{V}$ & Silangit, Sub-district Siborong-borong, District North Tapanuli & 44.15 & 0.916 \\
\hline VI & Parsoburan, Sub-district Parsoburan, District Toba Samosir & 53.96 & 0.912 \\
\hline
\end{tabular}

rounding farmers. All coffee samples in general were still fresh as big traders normally received. Table 1 shows origins, moisture contents and $\mathrm{a}_{\mathrm{w}}$ values of the parchment coffees used in this trial. The moisture content and $\mathrm{a}_{\mathrm{w}}$ were varied between 41.74 to $53.96 \%$. Normally, if the moisture is higher than $45 \%$, the parchments is sun dried to level $40-45 \%$, the suitable condition for wet-hulling. Standing of parchments at that high moisture contents is quite common at farmer or trader levels. It is due to the weather condition or price consideration. The area where the coffee produced is quite wet, the rain falls almost whole year. The main crop falls within the rainy season (September to January), and at the minor crop (March to August) the rain is sometime falls too.

$\mathrm{A}_{\mathrm{w}}$ values of stored parchments was still above 0.9 which still suitable for mould growth along with the storage course up to 14 days. The moulds only visibly grew on naked beans and broken beans of lot VI started at day 3 (Table 2). Lot VI was the most wet parchement compared with the others. On day 4 , the same condition was also present on Lot I, while limited moulds were also visible on the other lots. Black spots of mould spores appeared on the surface of those lots on day 5 and by next day black spots also present on all lots and more intensive on day 7 . In order to suppress mould growth, all lots of parchments were spreaded inside the warehouse, as normally traders do. Although the moisture content was still high, mould growth could be suppressed by the tratment. It was likely due to the $\mathrm{a}_{\mathrm{w}}$ of parchments bit reduced during the spreading, hence suppressed the mould growth. Mould visibly grow more intensive only on naked and broken beans. The condition remained up to 14 days of storage by controlling the parchment spreaded inside the warehouse during the day and collected back in the sack during the night.

In plants, there are peptides and proteins named defensins that actively produced in response to a large array of pathogens, as the innate immune system. Many defensins have been characterized, most of them from seeds of various plant species (Lay \& Anderson, 2005; Castro \& Fontes, 2005). The similar molecules might be play a defensive role in the stored coffee parch- 


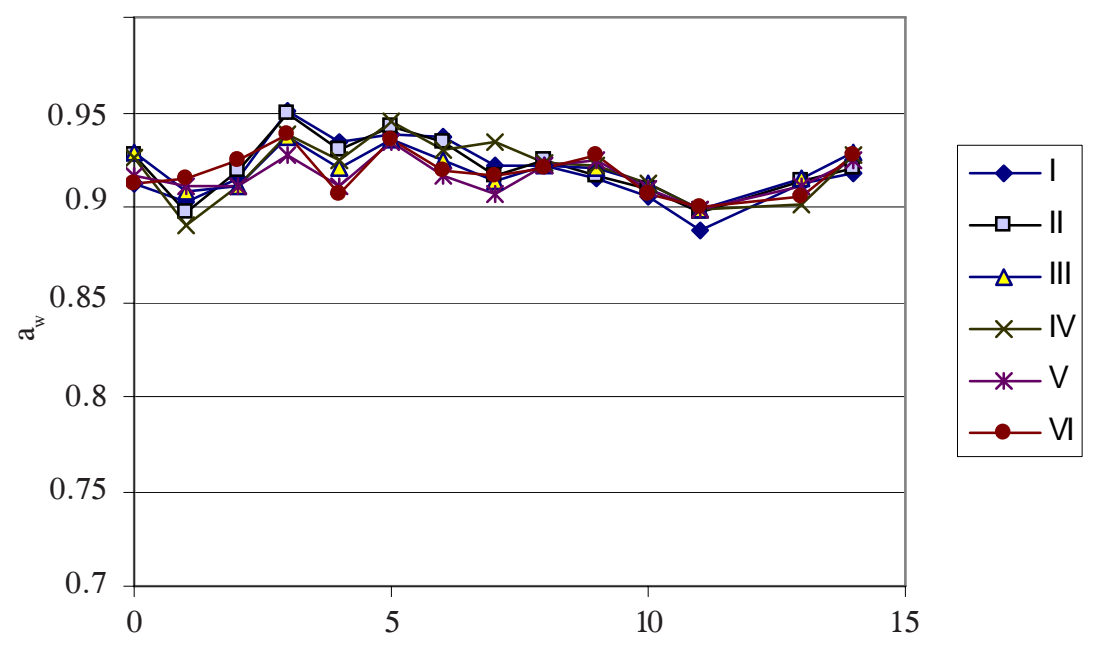

Storage period, days (Lama penyimpanan, hari)

Figure 1. $\mathrm{a}_{\mathrm{w}}$ of stored coffee parchments during storage course.

Gambar 1. Nilai $a_{w}$ dari biji kopi bercangkang selama penyimpanan.

ments that made the moulds could not grow intensively, although that has not been elucidated yet. Role of such defensins and physical conditions $\left(\mathrm{a}_{\mathrm{w}}\right.$, temperature and moisture content) might also have a significant role to suppress the mould growth during the storage. No such information available regarding such defensins in coffee seeds or parchments. A deeper study on that is still needed to uncover the mechanism.

\section{OTA contents}

OTA was present only in 5 treatments out of 42 trial units with relatively low values (Table 3). The low level and frequency of OTA contamination was bit surprising, since the coffee was partly mouldy. Control of storage by spreading the coffee inside the warehouse has effectively suppressed the mould growth and accumulation OTA in the beans. According to our survey data of some samples taken from some farmers and local traders in the region, OTA contamination level and frequency were also low. Only 2 out of 19 samples contained OTA with levels of 0.25 and $0.37 \mathrm{ppb}$, respectively (Ismayadi, unpublished data).

The presence of OTA in 3 samples of 14 days stored parchments, even at low levels could not be trivialized. It would be possible to get higher levels if the storage of wet parchments is out of control. Visual check of stored parchments (and beans) for mould growth have to be done intensively to control contamination of any mycotoxins in coffee beans. The control could be done by spreading the wet parchment inside the warehouse. 
Table 2. Visual appearance of stored coffee

Tabel 2. Penampakan visual dari biji kopi yang disimpan

\begin{tabular}{|c|c|}
\hline Day (Hari) & Visual appearance (Penampakan visual) \\
\hline $\begin{array}{l}\text { Day } 1 \text { and } 2 \\
1 \text { dan } 2 \text { hari }\end{array}$ & Coffee looked normal (Biji kopi tampak normal) \\
\hline $\begin{array}{l}\text { Day } 3 \\
3 \text { hari }\end{array}$ & $\begin{array}{l}\text { Mould visually start growing on naked and broken coffee beans of Lot VI (Jamur tampak mulai tumbuh } \\
\text { pada biji tanpa cangkang dan pecah pada lot VI) }\end{array}$ \\
\hline $\begin{array}{l}\text { Day } 4 \\
4 \text { hari }\end{array}$ & $\begin{array}{l}\text { Mould visually start growing on naked and broken coffee beans of Lot I and VI (Jamur tampak mulai } \\
\text { tumbuh pada biji tanpa cangkang dan pecah pada lot I dan VI) }\end{array}$ \\
\hline $\begin{array}{l}\text { Day } 5 \\
5 \text { hari }\end{array}$ & $\begin{array}{l}\text { Black spots start growing on the surface of parchments of Lot I and VI. (Bintik-bintik hitam mulai tumbuh } \\
\text { pada permukaan cangkang pada lot I dan VI) }\end{array}$ \\
\hline $\begin{array}{l}\text { Day } 6 \\
6 \text { hari }\end{array}$ & Black spots on all lots start to grow (Bintik-bintik hitam mulai tumbuh pada semua lot) \\
\hline $\begin{array}{l}\text { Day } 7 \\
7 \text { hari }\end{array}$ & Black spots on all lots more intensive (Bintik-bintik hitam pada semua lot lebih intensif) \\
\hline $\begin{array}{l}\text { Day } 8 \\
8 \text { hari }\end{array}$ & $\begin{array}{l}\text { All lots were spread on terpauline inside the warehouse, only during the day, and put back in the sack in } \\
\text { the afternoon, to suppress moulds growth (Semua lot dihamparkan pada terpal dalam gudang hanya pada } \\
\text { waktu siang dan dikembalikan ke dalam karung pada sore hari, untuk menekan pertumbuhan jamur) }\end{array}$ \\
\hline $\begin{array}{l}\text { Day } 9 \text { to } 13 \\
9-13 \text { hari }\end{array}$ & The same as the day 8 , to suppress moulds growth (Sama seperti hari 8) \\
\hline $\begin{array}{l}\text { Day } 14 \\
14 \text { hari }\end{array}$ & $\begin{array}{l}\text { The same as the day before, spots were not too excessive only broken beans were covered by moulds (Sama } \\
\text { seperti hari sebelumnya, bintik hitam terlihat tidak berlebihan, hanya biji pecah yang terbungkus jamur) }\end{array}$ \\
\hline
\end{tabular}

Control treatments, which expectedly free of OTA, 2 out of 6 lots were positively containing OTA, even with very low levels i.e. 0.73 and $0.79 \mathrm{ppb}$, respectively. It is likely that the OTA had accumulated during the drying process of parchments, which took 16 days to get moisture content less than $12 \%$. It might be possible that the OTA had already been accumulated before being used for this trial. Bucheli et al. (2000) confirmed that OTA was accumulated during drying of Robusta coffee. The prolonged drying process could deteriorate the coffee by infection of moulds. Mouldy taste may develop during the prolonged dry- ing process. Mandheling coffee is produced by fast drying of naked beans following the wet hulling. Normally it takes only 3-4 days to get final moisture content $12-14 \%$. By the process the coffee has unique appearance i.e. deep-blue colour and boat shape beans. The fast drying may also contribute the low OTA contamination of Mandheling coffee.

\section{Moulds Infection}

The most dominant mould species infested the beans of stored parchments before drying was black aspergilli, followed 
Table 3. OTA contaminated samples

Tabel 3. Contoh yang mengandung OTA

Treatments (Perlakuan)

OTA content (Kadar OTA), ppb

Storage day 14 of lot III, final MC $12 \%$ (Penyimpanan 14 hari, lot III, kd. air akhir $12 \%$ )

Storage day 14 of lot V, final MC $12 \%$ (Penyimpanan 14 hari, lot IV, kd. air akhir $12 \%$ )

Storage day 14 of lot V, final MC 17\% (Penyimpanan 14 hari, lot V, $k d$. air akhir 17\%)

by Flavi group and Penicillium spp. Some other un identifiable species were also present in the beans derived from the stored parchments (Table 4). A. ochraceus, an OTA producing species, was not found in beans derived from parchments after storage for 1 and 7 days, while it was found only in the parchment after stored for 14 days with very low rate of infection. It is likely that moulds infection rate tend to increased by storage period. Storage of parchment for 14 days is quite long in the coffee producing areas; normally traders hold the coffee only few days up to one week. Holding of wet parchment coffees for later than 2 weeks is uncommon.

Similar to the wet stored parchment, the most dominant mould species found in the coffee beans after drying was also black Aspergillus, followed by flavi group and Penicillium spp. (Table 5). A. ochraceus was found in very low frequencies and rates in some samples. That low frequencies and rates of infection was not surprising, since our surveys of mould infection in some other coffee producing areas in Lampung, East Java and Bali also found the same figure (Ismayadi \& Zaenudin, 2002). However, the presence of the species in coffee has to be worried since it potentially produces OTA if the prevailing condition suitable for growth and OTA synthesis. The wet parchment (with $\mathrm{a}_{\mathrm{w}}$ higher than 0.9) is potentially suitable for the mould species to grow and producing OTA. Therefore, a good control of storage condition to suppress the mould growth, like by spreading the parchment inside the warehouse, is required in order to avoid OTA and other mycotoxins contaminations. Since time is one of factors determined the mould growth and OTA accumulation, it is suggested to shorten the storage period when applicable.

\section{Cup Charateristics}

Mandheling coffee is an unique coffee with cup characteristic of low acidity, high-complex-rich body, spicy-little earthy and fruity flavor. Davids (1991) stated that Sumatra coffee (Mandheling and Gayo, respectively) has rich flavor, full body, gooddeep toned acidity, gentle-long finished and complex flavor and after taste. From the Internet search one can gleans some descrip- 
Table 4. Development of mould species during storage of wet parchments before drying

Tabel 4. Perkembangan spesies jamur selama penyimpanan kopi bercangkang sebelum pengeringan

\begin{tabular}{|c|c|c|c|c|c|c|c|}
\hline \multirow[b]{2}{*}{$\begin{array}{l}\text { Treatments } \\
\text { Perlakuan }\end{array}$} & & \multicolumn{6}{|c|}{ Mould infection rate (Tingkat infeksi), \% } \\
\hline & & $\begin{array}{c}\text { Black } \\
\text { Aspergillus } \\
\text { Hitam }\end{array}$ & $\begin{array}{l}\text { Flavi } \\
\text { group }\end{array}$ & A. ochraceus & Yeast & $\begin{array}{l}\text { Penicillium } \\
\text { spp. }\end{array}$ & $\begin{array}{c}\text { Other } \\
\text { species } \\
\text { Spesies lain }\end{array}$ \\
\hline D1 (day 1) & I & 0.0 & 0.0 & 0.0 & 0.0 & 4.1 & 20.4 \\
\hline \multirow[t]{5}{*}{1 hari } & II & 4.1 & 1.0 & 0.0 & 0.0 & 1.0 & 1.0 \\
\hline & III & 0.0 & 0.0 & 0.0 & 0.0 & 0.0 & 1.0 \\
\hline & IV & 0.0 & 0.0 & 0.0 & 0.0 & 4.1 & 10.2 \\
\hline & $\mathrm{V}$ & 0.0 & 0.0 & 0.0 & 0.0 & 4.1 & 13.3 \\
\hline & VI & 2.0 & 0.0 & 0.0 & 2.0 & 0.0 & 44.9 \\
\hline D7 (day 7) & I & 42.9 & 35.7 & 0.0 & 33.7 & 0.0 & 4.1 \\
\hline \multirow[t]{5}{*}{7 hari } & II & 96.9 & 87.8 & 0.0 & 0.0 & 0.0 & 30.6 \\
\hline & III & 26.5 & 40.8 & 0.0 & 6.1 & 11.2 & 17.1 \\
\hline & IV & 21.4 & 20.4 & 0.0 & 2.0 & 0.0 & 64.3 \\
\hline & $\mathrm{V}$ & 22.5 & 7.1 & 0.0 & 69.4 & 1.0 & 78.6 \\
\hline & VI & 45.9 & 8.2 & 0.0 & 21.4 & 0.0 & 61.2 \\
\hline D14 (day 14) & I & 64.3 & 36.7 & 0.0 & 11.2 & 0.0 & 42.9 \\
\hline \multirow[t]{5}{*}{14 hari } & II & 95.9 & 67.4 & 2.0 & 4.1 & 7.1 & 40.8 \\
\hline & III & 63.3 & 49.0 & 5.1 & 8.2 & 4.1 & 45.9 \\
\hline & IV & 57.1 & 41.8 & 7.1 & 1.0 & 0.0 & 53.1 \\
\hline & $\mathrm{V}$ & 87.8 & 25.5 & 4.1 & 8.2 & 0.0 & 44.9 \\
\hline & VI & 86.7 & 16.3 & 1.0 & 6.1 & 0.0 & 46.9 \\
\hline
\end{tabular}

tions of the coffee such as :

- "A heavy body coffee, without any acidity with full spicy flavour and a wonderful bouquet”.

- "Considered one of the world's finest coffees, undoubtedly the most full-bodied coffee available. Low in acid, but rich and smooth.

- "Very full body, very concentrated flavour. Sweet, slightly earthy, herbal nuances with a gutsy richness".

- "The flavors are sweet and somewhat earthy with pronounced herbal nuances.
The flavors and full body brought out by the roast make an exceptional cup. It's not the most refined or elegant coffee you can drink, but its gutsy and earthy richness is very seductive".

- "Sumatra has a full, syrupy body with virtually no acidity - so the coffee's intensity lingers in your mouth. The concentrated spicy, herbal notes and earthy aroma are the telltale signatures of this well-loved coffee".

We assumed that prevailing conditions of production and local trading have a significant influence on the development of 
Table 5. Moulds infestation in dried beans derived from parchments after 1,7 and 14 days of storage periods and controls

Tabel 5. Infestasi jamur dalam biji setelah pengeringan yang berasal dari kopi bercangkang setelah disimpan 1, 7 dan 14 hari dan kontrol

\begin{tabular}{|c|c|c|c|c|c|c|c|}
\hline \multirow[b]{2}{*}{$\begin{array}{l}\text { Treatments } \\
\text { Perlakuan }\end{array}$} & \multirow[b]{2}{*}{$\begin{array}{l}\text { Lot } \\
\text { Lot }\end{array}$} & \multicolumn{6}{|c|}{ Mould infection rate (Tingkat infeksi), \% } \\
\hline & & $\begin{array}{c}\text { Black } \\
\text { Aspergillus } \\
\text { hitam }\end{array}$ & $\begin{array}{c}\text { Flavi group } \\
\text { Kelompok } \\
\text { flavi }\end{array}$ & A. ochraceus & Yeast & $\begin{array}{l}\text { Penicillium } \\
\text { spp. }\end{array}$ & $\begin{array}{c}\text { Other } \\
\text { species } \\
\text { Spesies lain }\end{array}$ \\
\hline Day 1, mc $12 \%$ & I & 35.7 & 17.4 & 0.0 & 5.1 & 0.0 & 18.4 \\
\hline \multirow[t]{5}{*}{1 hari k.a. $12 \%$} & II & 58.2 & 3.1 & 0.0 & 1.0 & 0.0 & 2.0 \\
\hline & III & 21.4 & 6.1 & 0.0 & 2.0 & 17.4 & 7.1 \\
\hline & IV & 78.6 & 22.5 & 3.1 & 0.0 & 0.0 & 24.5 \\
\hline & $\mathrm{V}$ & 62.2 & 27.6 & 2.0 & 4.1 & 0.0 & 30.6 \\
\hline & $\mathrm{VI}$ & 53.1 & 36.7 & 1.0 & 7.1 & 5.1 & 15.3 \\
\hline Day 1, mc $17 \%$ & I & 21.4 & 2.0 & 0.0 & 3.1 & 17.4 & 0.0 \\
\hline \multirow[t]{5}{*}{1 hari k.a. $17 \%$} & II & 21.4 & 2.0 & 0.0 & 2.0 & 3.1 & 12.1 \\
\hline & III & 24.5 & 17.4 & 0.0 & 7.1 & 1.0 & 10.2 \\
\hline & IV & 50.0 & 6.1 & 1.0 & 40.8 & 0.0 & 14.3 \\
\hline & $\mathrm{V}$ & 20.4 & 5.1 & 0.0 & 1.0 & 0.0 & 10.2 \\
\hline & $\mathrm{VI}$ & 54.1 & 10.2 & 0.0 & 11.2 & 0.0 & 17.2 \\
\hline Day 7, mc $12 \%$ & I & 69.4 & 30.6 & 0.0 & 5.1 & 0.0 & 13.3 \\
\hline \multirow[t]{5}{*}{7 hari k.a. $12 \%$} & II & 82.7 & 43.9 & 0.0 & 9.2 & 0.0 & 17.3 \\
\hline & III & 52.0 & 24.5 & 1.0 & 7.1 & 0.0 & 14.3 \\
\hline & IV & 74.5 & 24.5 & 0.0 & 0.0 & 0.0 & 34.7 \\
\hline & $\mathrm{V}$ & 80.6 & 20.4 & 1.0 & 9.2 & 0.0 & 20.6 \\
\hline & VI & 79.6 & 22.5 & 1.0 & 2.0 & 0.0 & 45.9 \\
\hline Day 7, mc $17 \%$ & I & 72.5 & 23.5 & 0.0 & 7.1 & 2.0 & 21.4 \\
\hline \multirow[t]{5}{*}{7 hari k.a. $12 \%$} & II & 80.6 & 40.8 & 0.0 & 14.3 & 0.0 & 9.2 \\
\hline & III & 22.5 & 11.2 & 0.0 & 12.2 & 1.0 & 27.5 \\
\hline & IV & 63.3 & 9.2 & 1.0 & 11.2 & 0.0 & 40.8 \\
\hline & $\mathrm{V}$ & 63.3 & 12.2 & 1.0 & 7.1 & 0.0 & 34.7 \\
\hline & VI & 77.6 & 12.2 & 4.1 & 6.1 & 0.0 & 25.5 \\
\hline Day 14, mc $12 \%$ & I & 45.9 & 43.9 & 0.0 & 3.1 & 0.0 & 13.3 \\
\hline \multirow[t]{5}{*}{14 hari k.a. $12 \%$} & II & 61.2 & 36.7 & 0.0 & 7.1 & 0.0 & 24.5 \\
\hline & III & 82.7 & 48.0 & 2.0 & 8.2 & 0.0 & 17.4 \\
\hline & IV & 77.6 & 22.5 & 2.0 & 2.0 & 0.0 & 31.6 \\
\hline & $\mathrm{V}$ & 77.6 & 29.6 & 7.1 & 3.1 & 0.0 & 25.5 \\
\hline & $\mathrm{VI}$ & 67.4 & 21.4 & 0.0 & 5.1 & 0.0 & 37.8 \\
\hline Day 14, mc $17 \%$ & I & 83.7 & 38.7 & 0.0 & 21.4 & 0.0 & 28.6 \\
\hline \multirow[t]{5}{*}{14 hari k.a. $17 \%$} & II & 94.9 & 41.8 & 1.0 & 15.3 & 0.0 & 19.4 \\
\hline & III & 82.7 & 37.8 & 6.1 & 23.5 & 0.0 & 22.4 \\
\hline & IV & 96.9 & 25.5 & 7.1 & 6.1 & 0.0 & 67.3 \\
\hline & $\mathrm{V}$ & 85.7 & 34.7 & 15.3 & 41.8 & 0.0 & 41.8 \\
\hline & VI & 89.8 & 18.4 & 4.1 & 4.1 & 0.0 & 37.8 \\
\hline \multirow[t]{6}{*}{ Control (Kontrol) } & I & 57.4 & 13.3 & 0.0 & 4.1 & 0.0 & 22.5 \\
\hline & II & 57.1 & 7.1 & 1.0 & 7.1 & 0.0 & 13.3 \\
\hline & III & 11.2 & 3.1 & 0.0 & 13.3 & 1.0 & 2.0 \\
\hline & IV & 48.0 & 15.3 & 1.0 & 8.2 & 0.0 & 29.6 \\
\hline & $\mathrm{V}$ & 28.6 & 9.2 & 0.0 & 13.3 & 0.0 & 14.3 \\
\hline & VI & 74.5 & 17.4 & 0.0 & 3.1 & 2.0 & 50.0 \\
\hline
\end{tabular}


Mandheling cup characeristics. It is very common that the cup characteristic of Mandheling coffee is inconsistent from one lot to another. The inconsistency is likely caused by the variation of processes and handlings along the chain starting from farmer up to exporters. Storage of wet parchment to some extent was assumed to have a significant influence to the variation. Thus, we proposed to study the storage system the parchment in order to uncover the influence to cup characteristics and to analyse the OTA contamination status.

\section{Mandheling Character Rating}

The cup evaluation of samples was more emphasized on Mandheling cup character, since the coffee is has a unique character. Hence, we asked 4 coffee tasters who are familiar with Mandheling character. From cupping results of coffee beans derived from stored parchments up to 14 days, there was no clear trend of storage periods to the creation of Mandheling cup characteristics. Each of the 4 tasters rated the coffee from 1 (the worst Mandheling) to 10 (the best Mandheling). There is clear a range of coffees present. One taster's scores ranged from 1 to 10 , while another only ranged 3 to 5. The Highest and lowest ratings of each taster were compared to determine if there was any agreement between tasters. Most tasters gave higher scores (good to the best) Mandheling only 4 samples or less while they categorized more numbers of samples for lower scores (bad to the worst) Mandheling, even Taster-2 categorized 19 samples in the last category (Table 6). The other samples were categorized as a medium grade Mandheling. Each taster gave different figure for each categories, it might be due to the different perception about the Mandheling character among the taster for each samples. However, the sample from treatment D1-MC12\%-Lot 1 was scored the highest by three out of four tasters. Some other stored samples from D1, D7 and D14 treatments were also fallen in the best group while there also in the worst category. To get a clear trend of the influence of the storage treatment on the creation of Mandheling character it was likely need more uniform source of parchments. We used parchments from group farmers and local traders (also taken from many individual farmers) to get a sufficient amount, made it was not uniform within each lot. Those non-uniform lots could give inconsistent cupping results.

There was no control samples fell in the best category of Mandheling character except for the Lot IV which perceived by Taster-3. In general, control samples had a higher acidity and cleaner flavour compared with stored parchment samples. The high acidity of controls should different with Mandheling coffee which normally has low acidity. Apparently, slower drying of parchments produced higher acidity compared with the coffee dried in naked beans. Mandheling coffee is sun dried naked at one layer thickness for only 3-4 days, and the process produced dark-greyish-blue colour with boat shape as the consequence of the fast drying process. Normal mild Arabica process avoids the fast drying to get a higher acidity and mild flavour. 
Table 6. The high and low of Mandheling ratings scored by 4 tasters

Tabel 6. Nilai tinggi dan rendah terhadap karakter Mandheling oleh 4 pencicip

\begin{tabular}{|c|c|c|c|c|c|c|c|}
\hline \multicolumn{2}{|c|}{ Taster-1 (Pencicip-1) } & \multicolumn{2}{|c|}{ Taster-2* (Pencicip-2*) } & \multicolumn{2}{|c|}{ Taster-3 (Pencicip-3) } & \multicolumn{2}{|c|}{ Taster-4 (Pencicip-4) } \\
\hline $\begin{array}{l}\text { High rated } \\
\text { Dinilai tinggi } \\
(8-10)\end{array}$ & $\begin{array}{l}\text { Low rated } \\
\text { Dinilai rendah } \\
\quad(1-3)\end{array}$ & $\begin{array}{l}\text { High rated } \\
\text { Dinilai tinggi } \\
(8-10)\end{array}$ & $\begin{array}{c}\text { Low rated } \\
\text { Dinilai rendah } \\
(1-3)\end{array}$ & $\begin{array}{l}\text { High rated } \\
\text { Dinilai tinggi } \\
\quad(8-10)\end{array}$ & $\begin{array}{c}\text { Low rated } \\
\text { Dinilai rendah } \\
(1-3)\end{array}$ & $\begin{array}{l}\text { High rated } \\
\text { Dinilai tinggi } \\
\quad(8-10)\end{array}$ & $\begin{array}{c}\text { Low rated } \\
\text { Dinilai rendah } \\
\quad(1-3)\end{array}$ \\
\hline $\begin{array}{l}\text { D1-MC12\% Lot I, } \\
\text { D1-MC12\% Lot II, } \\
\text { D1-MC17\% Lot II, } \\
\text { D14-MC17\% Lot III }\end{array}$ & $\begin{array}{l}\text { Control-Lot I, } \\
\text { D7-MC12\% Lot I, } \\
\text { D14-MC12\% Lot I, } \\
\text { Control-Lot II, } \\
\text { D1-MC17\% Lot IV, } \\
\text { D7-MC12\% Lot IV, } \\
\text { Control-Lot VI }\end{array}$ & $\begin{array}{l}\text { D1-MC12\% Lot I, } \\
\text { D7-MC12\% Lot I, } \\
\text { D1-MC12\% Lot II }\end{array}$ & $\begin{array}{l}\text { Control-Lot I, } \\
\text { D7-MC17\% Lot I, } \\
\text { D14-MC17\% Lot I, } \\
\text { D7-MC17\% Lot II, } \\
\text { D14-MC17\% Lot II, } \\
\text { D7-MC12\% Lot III, } \\
\text { D7-MC17\% Lot III, } \\
\text { D14-MC12\% Lot III, } \\
\text { D7-MC17\% Lot IV, } \\
\text { D14-MC17\% Lot IV, } \\
\text { D7-MC17\% Lot VI } \\
\text { D7-MC17\% Lot V, } \\
\text { D14-MC17\% Lot V, } \\
\text { D7-MC12\% Lot VI, }\end{array}$ & $\begin{array}{l}\text { D1-MC12\% Lot I, } \\
\text { Control-Lot IV, } \\
\text { D14-MC12\% Lot IV, } \\
\text { D14-MC12\% Lot V }\end{array}$ & $\begin{array}{l}\text { D7-MC12\% Lot I, } \\
\text { D7-MC12\% Lot II, } \\
\text { D7-MC12\% Lot IV, } \\
\text { Control-Lot V, } \\
\text { D7-MC12\% Lot V }\end{array}$ & $\begin{array}{l}\text { D14-MC17\% Lot III, } \\
\text { D7-MC12\% Lot IV, } \\
\text { D7-MC12\% Lot V, } \\
\text { D14-MC17\% Lot VI }\end{array}$ & $\begin{array}{l}\text { Control-Lot I, } \\
\text { D1-MC12\% Lot I, } \\
\text { D1-MC17\% Lot I, } \\
\text { D7-MC17\% Lot I, } \\
\text { D1-MC12\% Lot II, } \\
\text { D7-MC17\% Lot II, } \\
\text { D14-MC12\% Lot II, } \\
\text { D14-MC17\% Lot II, } \\
\text { D1-MC17\% Lot IV }\end{array}$ \\
\hline
\end{tabular}

Notes (Catatan): * Taster-2 original scores given as rating from 1 to 7 and were converted to 1 to 10 for comparison. (Nilai dari Pencicip 2 semula 1 sampai 7 dikonversi menjadi 1 sampai 10 untuk pembandingan).

\section{Verbal Comments on Cup}

Verbal comments appear to relate to characteristics that clearly stand out in the cup. Many comments appear to be negative rather than positive. No instructions were given on how verbal comments should be made and the descriptions are those used by the tasters in their normal commercial assessments. There were some cup defects or taints perceived by the tasters i.e. fermented/ fruity, sour and musty. The first two taints only can be accepted at somewhat degree but not accepted if too tasteful. It caused by uncontrolled fermentation when the fresh coffee cherry or parchments stored in wet condition. It is difficult to compare the comments on the treatment and coffee sources, as each taster tends to have their own vocabulary and focus on specific characteristics of the coffees sample for their own commercial needs.
Verbal comments given by the tasters were inconsistent among the samples based on the storage periods and coffee sources (Table 7). It was likely due to the inhomogeneous parchments used for this trial.

Off-flavour fermented was perceived in some samples by 4 tasters. Sample D1MC17-Lot IV perceived by all tasters. Taster 2 perceived fermented in more number of samples compared to the other. Some of samples were perceived to have fermented flavour by 2 or 3 tasters, while mostly were perceived individually by each taster.

Musty flavour which caused by moulds was perceived only by Taster-1 in 9 samples, while the 3 other tasters did not perceived the off-flavour. Among 9 samples which perceived by Taster-1 having musty flavour 3 of them categorized as good to 
Table 7. Common characteristics described verbally in the samples be each taster

Tabel 7. Karakteristik seduhan umum yang diberikan secara verbal oleh setiap pencicip pada contoh hasil perlakuan

\begin{tabular}{|c|c|c|c|c|}
\hline $\begin{array}{l}\text { Character } \\
\text { Karakter }\end{array}$ & $\begin{array}{c}\text { Taster-1 } \\
\text { Pencicip-1 }\end{array}$ & $\begin{array}{c}\text { Taster-2 } \\
\text { Pencicip-2 }\end{array}$ & $\begin{array}{c}\text { Taster-3 } \\
\text { Pencicip-3 }\end{array}$ & $\begin{array}{c}\text { Taster-4 } \\
\text { Pencicip-4 }\end{array}$ \\
\hline Fermented/Fruity & $\begin{array}{l}\text { D1-MC17\% Lot IV, } \\
\text { D7-MC17\% Lot II, } \\
\text { D7-MC17\% Lot III, } \\
\text { D7-MC17\% Lot V }\end{array}$ & $\begin{array}{l}\text { D1-MC17\% Lot IV, } \\
\text { D7-MC12\% Lot III, } \\
\text { D7-MC17\% Lot I, } \\
\text { D7-MC17\% Lot II, } \\
\text { D7-MC17\% Lot III, } \\
\text { D7-MC17\% Lot V, } \\
\text { D7-MC17\% Lot VI, } \\
\text { D14-MC17\% Lot IV, } \\
\text { D14-MC17\% Lot V }\end{array}$ & D1-MC17\% Lot IV & $\begin{array}{l}\text { D1-MC17\% Lot IV, } \\
\text { D7-MC17\% Lot I, } \\
\text { D7-MC17\% Lot V, } \\
\text { D7-MC17\% Lot VI, } \\
\text { D14-MC17\% Lot II }\end{array}$ \\
\hline Musty & $\begin{array}{l}\text { D1-MC12\% Lot I, } \\
\text { D1-MC17\% Lot I, } \\
\text { D1-MC12\% Lot II, } \\
\text { D1-MC17\% Lot II, } \\
\text { D1-MC12\% Lot IV, } \\
\text { D1-MC12\% Lot V, } \\
\text { D1-MC12\% Lot VI, } \\
\text { D7-MC12\% Lot V, } \\
\text { D14-MC12\% Lot VI }\end{array}$ & & & \\
\hline Sour & $\begin{array}{l}\text { D1-MC12\% Lot IV, } \\
\text { D7-MC17\% Lot III, } \\
\text { D7-MC17\% Lot VI, } \\
\text { D14-MC12\% Lot V }\end{array}$ & & $\begin{array}{l}\text { D1-MC12\% Lot III, } \\
\text { D7-MC12\% Lot I, } \\
\text { D7-MC12\% Lot II, } \\
\text { D7-MC12\% Lot IV, } \\
\text { D7-MC12\% Lot V, } \\
\text { D14-MC17\% Lot I }\end{array}$ & \\
\hline Sweet & D14-MC12\% Lot III & & & D7-MC12\% Lot IV \\
\hline Acid & $\begin{array}{l}\text { Control Lot I, } \\
\text { D14-MC12\% Lot I }\end{array}$ & & D7-MC12\% Lot I & \\
\hline
\end{tabular}


the best Mandheling character by the taster (Table 6 and 7). It is well known that common Mandheling has little musty character, hence the presence of little musty flavour was likely associated to the Mandheling character by Taster-1.

Sour flavour was perceived only by Taster- 1 and Taster-3 in some samples but no one of them was consistently perceived by each of them. Other flavours sweet and acid perceived by Taster-1, Taster- 3 and Taster-4 in very few samples, again it was perceived differently among samples by each taster.

\section{CONCLUSION}

- The "best" Mandheling obtained from stored parchment for 1 day, wet hulled and dried directly to $12 \%$ promptly.

- Drying of parchment produced cleaner and more acidic coffees.

- Storage of wet parchment up to 14 days (with control) did not promote OTA contamination significantly (found only 5 out of 42 samples, with less level to European Union limit).

- No clear trend of strorage course of wet parchments and fast dryings to the creation of Mandheling characters.

\section{ACKNOWLEDGEMENTS}

This works has been supported by CFCFAO Project GCP/INT/743/CFC. We also acknowledge Mr. M. Glenister, Mr. S. Filiachi, Mr. G. Willekes, Mr. O. Tichit for the cuppings; Mr. Joko and Kusno of PT CBI at Siborong-borong for the field work facillities, and managements of Indonesian Palm Oil Research Institute at Medan and Pematang Siantar, North Sumatra for the Laboratory facilities. The acknowledgement also delivered to $\mathrm{Mr}$. Joko Sumarno, Mrs. Ninik Kusmiarsih for their assistance in the field and laboratory works.

\section{REFERENCES}

Bucheli, P.; C. Kanchanomai; I. Meyer \& A. Pittet (2000). Development of ochratoxin A during Robusta (Coffea canephora) coffee cherry drying. J. Agricultural and Food Chemistry, 48, 1358-1362.

Castro, M.S. \& W. Fontes (2005). Plant defense and antimicrobial peptides. Protein and Peptide Letters, 12, 13-18.

Davids, K. (1991). Coffee, A Guide to Buy, Brewing \& Enjoy. 101 Productions, Santa Rosa.

Frisvad, J.C. \& U. Thrane (1996). Mycotoxin production by food-borne fungi. p. 251260. In : Samson, R.A.; Hoekstra E.A.; Frisvad, J.C. and O. Filtenborg (Eds.) Introduction to Food-borne Fungi. Centraalbureau voor Schimmelcultures, Baarn.

Ismayadi, C. \& Zaenudin (2002). Pola produksi, infestasi jamur dan upaya pencegahan kontaminasi ochratoxin A pada kopi Indonesia, Warta Pusat Penelitian Kopi dan Kakao Indonesia, 19, 45-60.

Lay, F.T. \& M.A. Anderson (2005). Defensinscomponents of the innate immune system in plants. Current Protein and Peptide Science, 6, 85-101. 
Nakajima, M.; M. Tsubouchi; M. Miyabe \& Y. Ueno (1997). Survey of aflatoxin B1 and ochratoxin $\mathrm{A}$ in commercial green coffee beans by high-performance liquid chromatography. Food and Agricultural Immunology, 9, 77-83.

Ono, H.; A. Kataoka; K.M.K. Tanaka; S. Kawasugi; M. Wakazawa; Y. Ueno, \& M. Manabe (1995). Ochratoxin A Producibility by strains of Aspergillus niger group stored IFO culture collection, Mycotoxins, 41, 47-51.

Pittet, P.; D. Tornare; A. Hugget \& R. Viani (1996). Liquid chromatographic determination of ochratoxin A in pure and adulterated soluble coffee using an immunoaffinity column cleanup procedure. J. Agricultural and Food Chemistry, 44, 3564-3569.
Romani, S.; G. Sacchetti; C.C. Lopez; G.G. Pinnavaia \& M.D. Rosa (2000). Screening on the occurrence of ochratoxin A in green coffee beans of different origins and types. J. Agricultural and Food Chemistry, 48, 36163619.

Samson, R.A.; E.A. Hoekstra; J.C. Frisvad \& O. Filtenborg (1996). Introduction to Food-borne Fungi. Centraalbureau voor Schimmel-cultures, Baarn.

$* * * * * * * * * *$ 